\title{
IMPACTS OF TERRORISM-RELATED SAFETY AND SECURITY MEASURES AT A MAJOR SPORT EVENT
}

\author{
TRACY TAYLOR* and KRISTINE TOOHEY† \\ ${ }^{*}$ Graduate School of Business, University of Technology, Sydney, Broadway NSW 2007, Australia \\ $\dagger$ Department of Tourism, Leisure, Hotel and Sport Management, \\ Griffith Business School, Griffith University Gold Coast Campus, Australia
}

\begin{abstract}
In the aftermath of the September 11,2001 terrorist attacks, major sport event organizers have had to grapple with a range of associated impacts, including increased security costs and changed stakeholder expectations. Event organizers have acted to realize a balance between effective risk management measures that offer appropriate security while not unduly deterring from spectators' enjoyment of the event. To better understand the post $9 / 11$ sport event environment and attendee reactions, we surveyed 2003 Rugby World Cup attendees on aspects related to terrorism, risk, safety and security. We found that the majority of attendees felt safe and indicated that the security measures in place neither enhanced nor detracted from their level of enjoyment. A substantial proportion of event attendees were either openly defiant about terrorism or dismissive of any threat to their security. Implications for event managers are discussed.
\end{abstract}

Key words: Terrorism-related safety; Security measures; Sport events; Event impacts

On September 11, 2001 four commercial airplanes in the US were hijacked. Two of these crashed into the Twin Towers of the World Trade Centre (WTC) in New York City, one into the Pentagon in Washington, and the fourth into a field in Somerset County, Pennsylvania. These attacks are now commonly known as $9 / 11$. Global media coverage of the incident and subsequent renewed interest in terrorism by governments have contributed to a strategy of proactivity as one means to reduce the likelihood of further incidents. Immediately after 9/11 safety and security-related processes in airports, embassies, and public venues, such as sport sta- dia, were reexamined, additional surveillance equipment and personnel were required, and related risk management support was increased (Kennedy, Perrottet, $\&$ Thomas, 2003). The tourism industry across the world was severely affected by the $9 / 11$ terrorist attacks, with immediate declines in airline passenger loads and hotel occupancy rates. Oriol (2004) argued that many tourists felt uncomfortable traveling post-9/11, and inevitably their travel pattern and choices were affected.

Two years after September 11, 2001, and 3 years after hosting a very successful and safe Olympic Games, 
Sydney, Australia played host to the International Rugby Union Board's (IRB) Rugby World Cup (RWC). The venue and event managers instigated safety and security procedures to prevent and deal with the unlikely occurrence of a terrorist attack. What was the reaction by spectators to these procedures in this new era of heightened awareness of terrorism? It is important to empirically investigate whether or not terrorism influences tourists who are traveling specifically to consume sport (i.e., the sport tourist), because of the effect that tourism has on an event's economic impact (Lee \& Taylor, 2005). Understanding attendees' enjoyment of the event, their level of fan support, what enhanced and detracted from their experience, and if friends and family showed concern about their attendance is important for planning future sports events, as the theory of planned behavior "predicts that attitudes, subjective norms and perceived behavioural controls predict[s] a person's intention to participate in an activity" (Cunningham \& Kwon, 2003, p. 132).

In this article we explore: if terrorism-related safety concerns influenced attendees' decision making; the impact of the tightened security measures on spectators and their satisfaction with the event; and the effect that gender, age, nationality, and type of sport tourist had on these perceptions.

\section{Major Sport Event Research}

In trying to determine an appropriate contextual framework for research on sport events, Deery, Jago, and Fredline (2004) have argued that sport tourism has as its core sport event tourism. They suggest that future research is needed to profile its segments. However, we believe the research into major sport events should not be so narrowly classified and that our understanding about sport events can also be informed from a number of disciplines and other applied areas of study, including sport management, marketing, and tourism studies.

In its broadest sense sport tourism encompasses tourists who actively or passively participate in competitive or recreational sport (Gibson, 2002). As consumers of rugby matches, RWC attendees can be included in the category of those, "thousands of people travel significant distances to watch their favourite sports on a regular basis" (Gibson, Willming, \& Holdnak, 2003, p. 181). However, research on sport event tourists is rather limited, with the bulk of sport event tourism literature focusing on hallmark events, economic impacts, and destination marketing and imaging, not the spectators (Toohey, Taylor, \& Lee, 2003). In response to these limitations it is suggested that investigations of sport tourism research need to extend beyond the area of sport event tourism and include other theoretical approaches.

The concept of spectatorship, as a significant tourism experience and area of study, is only recently beginning to emerge. Research into the motivations of event sport tourists and the subsequent categorization and profiling of different types of fans (Diaz, 2003; Gammon \& Robinson, 2003; Ritchie, Mosedale, \& King, 2002) has started to build a body of knowledge. As distinct from team and professional sport fan identification, this research relates to the decision to travel and participate in or attend a sporting fixture (Kurtzman \& Zauhar, 2005).

In contrast, in the sport literature there is considerable research on the motives of sport spectators and fans (Funk, Mahony, Nakazawa, \& Hirakawa, 2001; Wann, Melnick, Russell, \& Pease, 2001; Zhang et al., 2001). An array of studies has sought to determine the psychological motivations that influence sport consumption (Funk \& James, 2001). While each study seems to propose a slightly different set of measures (see Trail, Anderson, \& Fink, 2000, for an overview), most agree that sport event attendee motives are multidimensional. Furthermore, in developing their model of team sport involvement Funk, Ridinger, and Moorman (2004) highlight the need to move the research beyond professional sport and collegiate teams to Olympic sport and other nonleague sporting events, and events in other countries and cultures.

In one of the few studies combining sport fan and travel motivation research in relation to a major event, Kim and Chalip (2004) explored event interest, risk constraint, and financial constraint with American soccer club members prior to the 2002 FIFA World Cup. The results of this study showed that event interest and constraints fully mediated the effects of motives, and the desire to attend the event was only affected by respondents' sense that going to Korea for the World Cup could pose health or safety risks for the individual. The results suggest that, "fans' attendance motivations need to be considered along with travel motives when seeking to identify the push factors that motivate travel to attend a sport event" (Kim \& Chalip, 2004, p. 696). Note that this research did not follow up the respon- 
dents to ascertain if those who indicated they would travel to the event actually did so.

There are a number of studies that have examined both direct and indirect influences of terrorism on tourism visitation and tourists, especially in the aftermath of 9/ 11 (Goodrich, 2002; Hall, 2002; Kuto \& Groves, 2004; Oriol, 2004). Terrorist actions or the perceived threat of these activities can serve to cause tourists to alter their travel behavior (Hall \& O'Sullivan, 1996; Hall, Timothy, \& David, 2003). Research in this area has attempted to determine what factors influence decisions about travel. Sönmez and Graefe (1998) found that tourists' decision making is influenced by a combination of risk, internal, external, and demographic factors, and both real and perceived risks associated with international tourism placed serious constraints on tourist behavior. Lepp and Gibson (2003) also investigated international tourists and perceived risk, and found that the perception of risk associated with terrorism varied significantly by tourist role. Organized mass tourists perceived terrorism as a greater risk than other groups, such as experienced independent travelers. In the following sections we explore how recent terrorism events have changed the focus of sport event organizers and impacted on the behavior of sport event tourists.

\section{The Context: Terrorism and Sport Events}

Since $9 / 11$, terrorism in other locations, such as Riyadh and Madrid, along with the continuing chaos in Iraq and Australia's role in the invading force, the exacerbation of violence and tensions in East Timor, continuing internal conflict in Indonesia, tensions in West Papua, intensified military operations in Aceh, and bombings in Jakarta and Bali, has kept discussions about the issue of terrorism in the public arena. Added to this, conflicts in the Southwest Pacific including the Solomon Islands, Bougainville and Fiji have continued to make news headlines in the Australian press. A complex interaction of economic turmoil, governance crises, politics, ethnic tension, religious and political violence, human rights abuses, state policy, and individual beliefs underlie these situations and have provided a fertile ground for terrorism to flourish and draconian antiterrorism measures to be imposed by governments.

Many service industries have suffered as a corollary of the terrorist attacks (Goodrich, 2002), and there have been dramatic and adverse consequences for event or- ganizers (Wicks, 2002). Specifically, sport events have felt both immediate and long-term financial impacts. In countries around the globe, in the ensuing months after $9 / 11$, numerous major sport events were cancelled or postponed, athletes made public decisions not to travel to events, and national teams withdrew from international competitions. These immediate effects have now dissipated; however, others, such as increased security costs and measures have, by necessity, continued.

Given that contemporary terrorists seek targets that will provide them with worldwide media coverage, mega sport events, such as the Olympic Games or World Championships, seem obvious potential targets. The size of the audience and the symbolic representation of values associated with the sport event help determine its "terrorism capital" (Toohey \& Taylor, 2006). This realization began as far back as 1972, at the Munich Olympic Games, when Israeli athletes and officials were killed by "Black September" terrorists. The world watched in horror as the drama unfolded on television screens, providing the terrorists with unprecedented media coverage. The enormity and immediacy of this momentous act of terrorism had ramifications beyond the Olympic event. Terrorists realized how the media could be exploited and focus the world's attention to their cause. For the Olympic movement this attack impacted on a number of levels, from increased costs to what Moore (1996) somewhat naively describes as the Olympics" "loss of innocence" (p. 30). Others would argue that the Olympics had already lost their innocence long beforehand, if indeed it ever really existed (Toohey \& Veal, 2000).

Since that 1972 incident, security at major sport events has tightened for athletes and officials, but sport events remain potential targets of terrorist threats, not only for these stakeholders but also for spectators, as was evidenced by the Centennial Park bombing at the 1996 Olympic Games. Major sport events now require far more sophisticated security planning; however, while this may have prevented some attacks, it has also resulted in some unintended negative outcomes. For example, at the 1976 Games security was so intrusive that the, "Village might well have been a prison camp" (McIntosh, 1984, p. 26). Despite this assessment, the security framework developed for the 1976 Games has provided the paradigm for all subsequent Olympic operations (Kennelly, 2005).

The 9/11 terrorist attacks further exacerbated the situation. Sport event organizers were required to imple- 
ment even more sophisticated, expansive, and expensive security measures. Some sport events and tours were cancelled. For example, the New Zealand Cricket team did not play its scheduled 2003 World Cup matches in Kenya after its Board concluded that safety and security risks for the players were too high, due to a "credible" terrorist threat in Nairobi. India's 2004 cricket tour of Bangladesh was put on hold because of a terrorist threat to kill its squad members. A hand-written fax indicated that if the team visited Bangladesh, they would be killed in revenge for the riots in the western Indian state of Gujarat in early 2002, which had left at least 2000 people dead, most of them Muslims (Australian Broadcasting Commission, 2004). It is not only the event organizers and players that are susceptible to terrorism but also sport consumers, notably spectators. In December 2004, as a result of a bomb threat, a Real Madrid versus Real Sociedad match was suspended with less than 5 minutes left to play and an evacuation of the stadium was ordered by the authorities. And the list goes on.

The 2004 Athens Olympics is estimated to have spent over US\$1 billion on safety measures. Before the Games there were many media reports of the possibility of terrorist attacks at these Games. Some analysts claimed that the Greek government had been downplaying the risks involved despite the fact that the national government had passed antiterrorism legislation and implemented unprecedented security planning (Kennelly, 2005). Even with these initiatives it was rumored that the US team would withdraw if the perceived threat of terrorism was too high (Dahlberg, 2004). In the face of this criticism, Athens Mayor Dora Bakoyianni, noted that, "we are paying the price for September 11" (Lui, Vlahou, \& Robert, 2004, p. 22).

Despite the security precautions taken and the assurances given by Games organizers it has been suggested that the fear of terrorism may have contributed to low spectator numbers. According to Cashman (2004), "various theories have been advanced to explain the no-show Olympics. One is that the events started on a holiday weekend and another is that there is limited interest in the preliminary stages. But the most popular theory is that the Athens Olympics, being the first Summer Games since September 11, are a casualty of increased security fears" (p. 1). Other major sport events have also seen a decline in travel numbers of the less committed sport fans (Wicks, 2002). At present, event organizers are placed in a paradoxical situation; on one hand major events are dependent on the media for information dissemination, marketing, and sponsorship (Allen, O'Toole, McDonnell, \& Harris, 2005). On the other hand, an increased media profile heightens the attractiveness of the event as a terrorism target and may impact on spectator numbers and their experience (Tarlow, 2002).

\section{The Rugby World Cup: Security and Safety}

The first Rugby World Cup (RWC) was held in 1987. Since then the tournament has developed to be arguably the third largest sporting event in the world, in terms of the numbers of spectators and television audience, ranking only behind the Olympic Games and the FIFA World Cup. The RWC follows a 4-year cycle and is held the year after each FIFA World Cup and the year before the Summer Olympic Games. The event is seen as an opportunity for both the tourism industry and the host country to project a modern and attractive image to existing and new markets and to capitalize on the considerable media attention to heighten and profile destination branding and awareness.

The 2003 RWC was staged in Australia over 44 days, from October 10 to November 22. The sport's international governing body, the International Rugby Board (IRB), controlled the commercial aspects (broadcasting rights, sponsorship, and licensing) of the tournament and the national governing body, the Australian Rugby Union (ARU), had responsibility for its organization and staging (Australian Department of Industry, Tourism and Resources, 2004). It was the largest sporting event to be held in Australia since the 2000 Sydney Olympic and Paralympic Games. In total there were 48 matches, held in 11 venues in 10 cities (Adelaide, Brisbane, Canberra, Gosford, Launceston, Melbourne, Perth, Sydney, Townsville, and Wollongong), attracting 4.3 million domestic television viewers and $1,850,000$ spectators. Ninety-one percent of available seats were occupied (ARU, 2003).

Early estimates had predicted that up to 75,000 international visitors would attend the event, coming primarily from New Zealand, the UK, and Europe. However, these calculations had been revised down to as low as 40,000 in mid-2003. The event organizers believed that the lower than expected sales of ticket packages overseas were due to international travel concerns over the outbreak of the SARS virus in Asia, and the ongoing terrorism debate fuelled by the war in Iraq 
(Australian Department of Industry, Tourism and Resources, 2004, p. E-3). Despite these impediments, the economic impact of the tourists to Australia was estimated to be close to A $\$ 1$ billion and the tournament revenue exceeded the budget by A\$15.5 million (ARU, 2003).

The issue of terrorism was germane to the planning and staging of the RWC. The tournament was held only 2 years after $9 / 11$ in which 15 Australians died, and 1 year after the Bali bombings, which killed a further 88 Australians and injured over 100. The Bali attacks, which had targeted Australian tourists, and killed/injured a number of visiting Australian rugby players, raised the possibility of future terrorism occurring on Australian soil. Some people believed this likelihood was increased when the Australian government joined the US-led "coalition of the willing" in Iraq. Because of this, the Australian, English, and US teams received added security during the RWC (Australian Broadcasting Commission, 2003). According to Andrew Metcalfe, Deputy Secretary of the Department of Prime Minister and Cabinet (2004):

While in most aspects the 2003 Rugby World Cup was an international sporting event with no particular security imperative, special planning was required because of several factors: the presence of teams from the USA and the UK, both countries at a higher level of threat than Australia in general; the presence of members of the British royal family as private visitors; the likely presence of many other VIP visitors, some likely to attend at the last minute depending on the progress of their teams; and the need to plan in case the threat to the games increased.

While the event had been considered by experts as low risk, there were external terrorist-related factors that occurred during the tournament that impinged on its management. Three days before the final, the US government had issued a terror alert for its interests abroad. At the same time the UK added Australia to the list of countries that could be targeted by car bombs. Then a terrorist attack in Istanbul and threats of further violence against Western targets prompted Australia's Foreign Minister, Alexander Downer, to urge Australians overseas not to gather in large groups in public places, such as bars and hotels, to watch the final (Walsh, 2003). Despite the heightened possibility of attack there were no terrorist incidents.

After the event the Queensland police issued a review of their RWC security arrangements for the 12
World Cup games in the state. The report indicated 846 objects considered to be dangerous (including kilt pins, a traditional Scottish dagger, cans and bottles) were confiscated from spectators. Thirteen percent of the 457,540 spectators attending Queensland matches had their bags searched, while 669 people were electronically scanned (Todd, 2004). The ARU 2003 Annual Report noted that "venue security was appropriate for an international event ... even the large and boisterous crowds, who enjoyed imbibing, were well behaved, before, during and after the matches. This was commented on by all police forces, which allowed them to have a good time" (ARU, 2003, p. 54). Thus, the event organizers were cognizant of the need to balance this aspect of spectator enjoyment and security requirements. This study aimed to assess how successful the event organizers were in achieving this balance.

\section{Research Method}

Perceptions of how safety impacted levels of enjoyment data were collected by a convenience-based sample of RWC spectators from the three New South Wales cities that hosted matches (Sydney, Wollongong, and Gosford). In all cases the surveys were conducted before kick off to best ensure that fan responses would not be unduly influenced by spectator inebriation, a not unknown consequence of alcohol consumption while watching rugby games. Observably intoxicated individuals were not sampled; however, it is acknowledged that this potential influence on responses cannot be totally discounted, even with this preventative measure.

The survey was administered by interviewers trained by the research team and conducted only in English. At each location between two and five interviewers randomly stopped pedestrians and asked if they: understood spoken or written English; were willing to answer questions about the RWC; and had already attended a RWC match. Upon agreeing to these points, a self-complete questionnaire was provided, or the field researchers completed the questionnaire via personal interview. Five hundred and eleven questionnaires distributed were fully completed and deemed usable. Less than 20 potential respondents were unable to proceed with the questionnaire due to the English language restriction.

The survey was conducted on game days. In Wollongong and Gosford, questionnaires were administered close to the match venues. ${ }^{1}$ In Sydney, event 
attendees were surveyed at the entrance to Central Train Station and the Darling Harbour live site, where RWC matches were broadcast on a big screen. The live site broadcasts formed part of the RWC Tournament program of "city festivities," organized by the ARU and State and territory governments. Central station was selected as a data collection site in order to capture RWC attendees traveling by train to matches at Olympic Stadium or catching buses to the games at the Sydney Football Stadium.

The questionnaire included questions on perceptions of security that had been used in research on 2002 FIFA World Cup (Toohey et al., 2003) and fan identification items, previously used in a study of rugby union fans (Ritchie et al., 2002). In research on the concept of sportrelated tourism Ritchie et al. (2002) developed a framework for profiling spectators at the Super 12 Rugby Union competition in Canberra. Given the similar nature of this event to the RWC we employed similar classifications as those developed by Ritchie et al. as a framework for conducting our research. This included using the same items to measure sport tourist spectators' sporting behavior such as their active involvement in sport and sporting clubs, motivations toward sport and travel, and their subsequent tourism and travel behavior, such as expenditure patterns, involvement in activities and attractions, and length of stay. The use of this research provided us with a useful point of comparison, because the Super 12 study was conducted in 2000 , prior to the $9 / 11$ terrorist attacks and the Bali bombings and the RWC was after these events.

Factors influencing audience's perception of safety and their impact on enjoyment required the development of different constructs to capture a better explanation of the phenomenon. These constructs included "identification with Rugby," measured by their affiliation with the sport, "key reasons for event attendance," "perception of stadium security," "perception of security/safety at the RWC," "level of enjoyment," and demographic questions covered gender, age, level of education, group size, and place of residence.

Key reasons for RWC attendance were measured by a Likert scale ( 1 = totally unimportant, $5=$ very important $)$ for 11 items: "Once in-a-lifetime opportunity," "Cheering and supporting your team," "Being a big fan of World Cup Rugby," "It's part of a holiday," "Visiting friends and relatives," "Business/networking opportunities," "Social experience," "Availability of Games ticket(s)," "Affordable," and "Sydney is a safe destination."
The security related items consisted of a set of eight questions enquiring about respondents' experiences of the event. These were measured on a 5-point Likert scale ( 1 = very safe, $5=$ unsafe). Similarly, "enjoyment" was also measured on a Likert scale.

Respondents were asked to rank the obviousness of security measures at a number of locations, such as "airport," "defense forces," "stadium," "transport," "accommodation," and "police." However, the respondents may not have been exposed to all of these. Therefore, "perception of stadium security" was used as a single security perception item.

Respondents were also given the opportunity to comment, via three open-ended responses, on the impact of terrorism on sport, about their perceptions of security issues, and to provide suggestions on security measures that might help the organizers of future large sporting events. These open-ended responses were deemed to be important as they were seen to be able to provide deeper insights into the respondents' attitudes to terrorism and its relationship to sport.

\section{Findings}

Of the 511 respondents, $65.4 \%$ were domestic tourists and $34.5 \%$ were visiting from one of 19 overseas countries, with the largest grouping coming from Great Britain. Males (75\%) were the dominant gender in the sample, slightly higher than the Ritchie et al. (2002) study finding of $67 \%$ male attendees to the Rugby Super 12 games. There was a wide representation of age groups (mean $=32$ ) in the sample. A high proportion (44\%) attended with at least one other person. Only a few visitors indicated that they were attending the game alone $(11 \%)$. On average respondents attended two RWC games. Table 1 summarizes the key sample profile elements.

Not surprisingly, the results indicate that the RWC in itself was a major drawcard for the attendees. Table 2 shows the relationship between each of the attendee categories to the importance they attach to reasons for coming to the event. For the "avid" attendees being a "big fan of RWC" was the most important reason for their visit; this was followed by "cheering their team" and the "social experience." At the other end of the spectrum, those attendees who noted that they were "not a fan" rated the social experience of the event as by far the most important, followed by "once in a lifetime opportunity" and "Sydney as a safe destination." 
Table I

Study Sample Profile

\begin{tabular}{lc}
\hline Category/Characteristic & \% of Sample \\
\hline Country of origin & \\
Australia & 65.4 \\
UK & 20.8 \\
Other Europe & 6.0 \\
New Zealand & 2.8 \\
Other & 5.0 \\
Gender & \\
Male & 7.48 \\
Female & 25.2 \\
Education & \\
University degree & 58.9 \\
College/TAFE & 20.2 \\
High school or less & 20.9 \\
\hline
\end{tabular}

These outcomes are similar to the Ritchie et al. (2002) study in finding that being a rugby fan was more important to the "avid" group. However, there were differences. In our study "visiting friends and relatives" and "having a holiday" were most important to the "avid" spectators, and less important to the other groupings; this is opposite to the Ritchie et al. study. It is also noteworthy that the "not a fan" attendees indicated that "business networking" was significantly more important to them than it was for any of the other types of attendees.

\section{Attendee Perceptions of Safety and Attendee Type}

Attendees were asked to rate their perceptions of safety based on a range of situations and locations encountered during their visit. Some $60 \%$ of visitors indicated that it was important to them that Sydney was a safe destination. Specific, event-related locations (ven- ues, transport, airport, and accommodation) were also ranked. The match venue generated the highest mean in terms of perceptions of safety, where security checks and the presence of police and other spectators created a perception of a safe visitor enclave. Perceptions of safety in the stadium were significantly higher among overseas attendees when compared to domestic attendees, largely due to the high "neutral" response of local residents. Less important to both international and domestic attendees were the security measures in place on public transport and in their accommodation.

Overall, perceptions of safety were favorable: some $99 \%$ of visitors felt safe during the event, with only $2 \%$ overall indicating that they considered not attending the RWC due to safety concerns, and only a small number $(4 \%)$ indicated that family or friends were concerned about their decision to attend the World Cup because of possible terrorist attacks. The perceptions among attendees of overall safety were not significantly different between males and females. Results also indicated that the security measures enhanced $21 \%$ of attendees' level of enjoyment of the game.

In line with Ritchie et al.'s 2002 study, responses were calculated by attendee type and sporting behavior (Table 3) to examine whether respondents' self-selection as an "avid," "frequent," "casual," or "not a fan" category was confirmed by their sport-related behavior. The results indicate that "avid" attendees were most active in sport and in rugby. The most significant difference was for holders of rugby season tickets with "avid" attendees over fives times as likely to be ticket holders than the "frequent" group. Second most significant was the difference in the category of "play an active role in rugby union." Our finding is different to the Super 12 study in two ways: firstly, we found that difference between "avid" and "frequent" in season ticket owner-

Table 2

Spectator Type Versus Importance to Attendance

\begin{tabular}{lccccc}
\hline Important/Very Important & Avid (\%) & Frequent (\%) & Causal (\%) & Not a Fan (\%) & Total (\%) \\
\hline Once in a lifetime opportunity & 83.4 & 85.5 & 87.0 & 61.1 & 84.0 \\
Cheering team & 87.9 & 95.2 & 82.5 & 33.4 & 84.8 \\
Big fan of RWC & 94.4 & 83.1 & 55.5 & 5.6 & 73.0 \\
Holiday & 43.0 & 41.5 & 19.8 & 27.8 & 33.4 \\
Visiting friends \& relatives & 22.5 & 15.6 & 8.7 & 17.7 & 15.5 \\
Business networking & 11.1 & 6.0 & 9.8 & 29.4 & 10.2 \\
Social experience & 87.1 & 84.3 & 86.9 & 77.8 & 85.8 \\
Sydney is a safe destination & 69.1 & 63.7 & 66.2 & 60.6 & 66.4 \\
\hline
\end{tabular}


Table 3

Attendee Type by Sporting Behavior and Safety Perceptions $(N=511)$

\begin{tabular}{lcccc}
\hline & Avid (\%) & Frequent (\%) & Casual (\%) & Not a Fan (\%) \\
\hline Male & 88.9 & 79.5 & 63.2 & 44.4 \\
Female & 11.1 & 20.5 & 36.8 & 55.6 \\
Active sport participant & 55.6 & 52.4 & 46.2 & 27.8 \\
Play an active role in Rugby & 51.9 & 27.7 & 4.3 & 0.0 \\
Regular Rugby spectator & 75.9 & 61.4 & 7.7 & 0.0 \\
Rugby season ticket holder & 18.5 & 3.6 & 0.0 & 0.0 \\
Felt safe/very safe at RWC & 80.5 & 85.4 & 67.8 & 72.3 \\
Security enhanced RWC experience & 20.6 & 20.7 & 10.3 & 13.3 \\
Considered not coming due to safety concerns & 0.0 & 1.2 & 2.6 & 0.0 \\
\hline
\end{tabular}

ship was much more pronounced for RWC attendees than it was for Super 12 spectators, and, secondly, we found the RWC "avid" attendees were much more likely to play an active role in rugby (Ritchie et al., 2002).

In relation to safety issues, an aspect not explored in the Super 12 survey, there was no significant difference between "avid" and "frequent" attendees in terms of how safe they felt at the event or whether the event security enhanced their experience.

Descriptive analysis indicated a number of relationships. In terms of safety, the more obvious the stadium security, the safer attendees felt at the game; younger attendees felt safer than older ones; and the more important that attending RWC as a fan was, the safer they felt. The more important cheering for their team was, and the greater the importance attached to attendance being a once in a lifetime opportunity, the more spectators enjoyed the game.

However, due to the limited amount of variance reported on "feeling safe," further analysis was not viable. While respondents noted that their feelings of safety contributed to the enjoyment of the games, there was no reciprocal relationship between "feeling safe" and "enjoyment of the game" $(p<0.05)$. However, feeling safe only explained $8 \%$ of the variance of "enjoyment." This result indicates that safety is just one factor influencing the audience's level of enjoyment of the RWC.

The questionnaire contained an open-ended section where respondents were asked to discuss if terrorism had an impact on their attendance. The majority of comments fell into two categories. Firstly, those attendees who were dismissive of any potential threat included comments such as: "it's not like they'll blow us all up" and "it's all hype." Second, were those who expressed defiance: "don't let them win-sport is above politics," "sport should not be affected by political terrorists," "I live in North America and have seen a nation cowed. I refuse to give in," and "stay away from our country!!"

\section{Discussion}

The data collected for this study have shown that while there were some differences in perceptions of safety between different types of attendees, the vast majority of people going to the RWC felt very safe. While $9 / 11$ security requirements added substantial costs for event organizers, the actual attendees were notably unconcerned about their security. The neutrality of feelings about the security associated with the RWC is likely to be reflective of the visible, yet unobtrusive, presence of police and security. The presence of RWC enclaves (e.g., the Darling Harbour live site and nearby bars and restaurants) may have added to increased confidence in safety. It is notable that the perception that Sydney is a safe destination was important to the majority of attendees.

The increased security fears and decline in travel of less committed sport fans that have been associated with recent major events (Cashman, 2004; Wicks, 2002) were not evident among the participants interviewed at the RWC 2003. The respondents did not present notable safety fears, and attendees were not limited to committed rugby fans. The findings of the sample would suggest that safety concerns did not have an impact on their attendance decisions. An obvious limitation of the study is that the respondents were all attendees, and thus we cannot make any claims about the impact of security concerns on prospective RWC spectators who chose not to attend the event. 
The RWC safety and security procedures instigated by the event organizers were viewed with resounding neutrality by the event attendees. Safety issues had little bearing on the experience of the event for those who made the decision to attend a RWC game. Only a small proportion of the visitors reported that the tightened security measures enhanced their enjoyment of the event. While the profiling of attendees by spectator type produced a number of useful comparisons on sport event travel motivation with previous Super 12 research (Ritchie et al., 2002), the differences between types was not significant in relation to the event safety and security items.

The perceived threat of terrorism had minimal impact on event attendees' enjoyment of the sport spectacle. These findings suggest that the security measures employed by the event organizers were visible but not obstructive. The friendliness of those associated with the RWC, good lighting in public spaces, and the cleanliness and upkeep of the event venues may have also enhanced safety perceptions as these factors have previously shown to increase perceptions of safety (Barker \& Page, 2002).

Did the media play a role in downplaying the potential threat? Litvin's (2004) conclusion that while the media can escalate negative aspects related to destination image in a crisis, they can also do the opposite may have resonance here. A media search of the keywords "terrorism and the 2003 Rugby World Cup" using Factiva on all major Australian newspapers in the 6-month period leading up to the event, and during the World Cup (May 22, 2003 until November 22, 2003), turned up only nine stories about RWC safety concerns. There were no obvious attempts to engage public opinion by "fanning the flames" or producing a "moral panic," as had been found elsewhere, in the immediate aftermath of 9/11 (Johnson, 2001; Merari, 2002; Toohey $\&$ Taylor, 2006). Additionally, the increasing temporal distance between $9 / 11$ and the RWC could be a factor in this discrepancy.

Our findings both supported and were in contrast with aspects of previous research into the effects of terrorism on tourism. Sönmez and Graefe (1998) found that international tourist decisions and real or perceived risks resulted in serious constraints on tourist behavior. Having made the decision to attend, those surveyed in this study were, in effect, self-selecting. Therefore, it is not entirely surprising that these attendees were not constrained by perceptions of terror as, by and large, they did not perceive any risk. Lepp and Gibson (2003) found that terrorism-associated risk varied significantly by tourist role, with organized mass tourists perceiving terrorism as a greater risk than other groups, such as experienced independent travelers. We did not find significant differences between committed rugby fans and non-fans, nor were there differences in perceived risk between single attendees, couples, independent groups, and organized tour parties. Nor could we find support for Oriol's (2004) argument that post-9/11, many tourists felt uncomfortable traveling, and this feeling altered travel patterns and choices.

Kim and Chalip's (2004) study of potential travel to the 2002 FIFA World Cup in Korea found that although risks were not generally identified as a constraint to travel, the higher the perception of risk, the less desire respondents had to attend the event. Interestingly, in their study, risks were positively related to respondents' perceived ability to attend, which led them to suggest that "as one feels more able to go, one's safety if attending may become a matter of greater concern" (Kim $\&$ Chalip, 2004, p. 703). In our study of RWC event attendees we found that they were relatively dismissive of potential terrorist acts occurring at the event, and a significant proportion of attendees were flippant or aggressively defiant. These findings would suggest that after the decision to travel has been taken, and the individual is committed to attending the event, their anxiety about safety and security diminishes, and is replaced by compliancy, dismissiveness, or open cheekiness. This finding fits with suggestions that $9 / 11$ changed the psychology of travel (Goodrich, 2002).

However, we note that the sample did not include people who did not travel to the RWC because of safety concerns. Given the broad range of nationalities and characteristics of attendees, determining who might be a "potential but not actual attendee" and surveying a range of them was deemed not viable.

\section{Implications for Event Managers}

There are a number of ways that future research can build on these findings and further develop our understanding of sport event management in a post-9/11 world. Firstly, there is the value of this study in developing insights to advance theory to better understand and predict future sport event consumption, as "previous behaviour significantly influences intentions and future behaviour" (Cunningham \& Kwon, 2003, p. 132). 
Thus, a positive experience at the RWC 2003 can assist organizers to build repeat attendances at future rugby events.

By enhancing the appreciation of the wants and needs of spectators and then marrying these with organizers' legal and operational imperatives, fans should have positive experiences. One facet of this is the perceptions of spectators about security and how this impacts on their enjoyment. Thus, event organizers can work to ensure that appropriate actions are taken to satisfy these consumers' enjoyment, and to encourage repeat attendance, while not downgrading security measures to the extent that they are risking safety. As over $63 \%$ of respondents traveled in a group, the sociability of the experience was important for them. Future antiterror security measures should take this into account.

"Past research has shown that positive attitudes towards a sport event are strongly associated with intentions to consume that event" (Cunningham \& Kwon, 2003, p. 132). Then for future organizing committees of the RWC, it is worth noting that the security measures enacted at RWC 2003 were shown to be of a positive nature that could be replicated, or modified, as the political and cultural situation warrants. Similarly, sport organizers need to understand that: there are different levels of fandom; different perceptions of whether or not security measures enhance or detract from spectator enjoyment; and a range of different demographics within their spectator base (with inherent cultural implications). More work is needed to explore the underlying causes and consequences of sport event attendees' motives and their effects on travel to attend an event. To do so it is important to understand sporting cultures, as well as the event related aspects. These may differ between sports or even within a sport depending on the level of fandom, as well as historical and social factors.

Perhaps, instead of proposing a narrowing of the framework of sport tourism as Deery et al. (2004) have argued, the opposite approach would be more fruitful. While their focus is on defining and segmenting markets, sport tourism, as an area of study, may benefit from being investigated by a broad range of academic disciplines and by researchers who follow Gibson's (2002) more encompassing definition. This points to a potentially larger discipline divide: is it a difference between researchers who come out of tourism, event, or sport paradigms, who presume their histories, interests, and agendas should drive and also limit research.

\section{Note}

${ }^{1}$ We were initially granted permission by the venue operators conduct the survey in the venue precinct, and this consent was in turn approved by the ARU. However, the IRB, which had ultimate decision-making authority, denied our request for access, despite our agreement to the initial terms of reference supplied to us. While we were not given an official reason for this rejection, we were told unofficially that the IRB, via their marketing partner IMG, was concerned that the openended questions may result in negative comments about RWC ticket package prices.

\section{References}

Allen, J., O'Toole, W., McDonnell, I., \& Harris, R. (2005). Festival \& special event management (3rd ed.). Milton, Queensland: John Wiley and Sons.

Australian Broadcasting Commission. (2003). Aust, England, US get extra Cup security. http://www.abc.net.au/sport/content/s962584.htm (retrieved May 24, 2004)

Australian Broadcasting Commission. (2004). http:// www.abc.net.au/sport/content (Retrieved December 3,2004)

Australian Department of Industry, Tourism and Resources. (2004). Economic impact of the Rugby World Cup 2003 on the Australian economy - post analysis. Canberra: URS Finance and Economics.

Australian Rugby Union. (2004). Annual report 2003 (pp. 52 56).

Barker, M., \& Page, S. (2002). Visitor safety in urban tourism environments: The case of Auckland, New Zealand. Cities, $19(4), 273-282$.

Cashman, R. (2004). Athens 2004, the no-show Games. National Forum. Online Opinion. http://www.onlineopinion.com.aw view.asp? article $=2490$ (retrieved august 15,2005 )

Cunningham, G., \& Kwon, H. (2003). The theory of planned behaviour and intentions to attend a sport event. Sport Management Review, 6, 127-145.

Dahlberg, T. (2004, July 5). U.S. debates on sending team to Athens Olympics. The Battalion Online, p. 1. http://www. thebatt.com/media/paper657/news/2004/05/07/Sports/U.sDebates.On.Sending. Team.To.Athens.Olympics679534 .shtml?norewrite\& sourcedomain =www thebatt.com

Diaz, A. (2003). Sports tourism markets. Journal of Sport Tourism, 8, 95-96.

Deery, M., Jago, L., \& Fredline, L. (2004). Sport tourism or event tourism: Are they one and the same? Journal of Sport Tourism, 9(3), 235-245.

Gammon, S., \& Robinson, T. (2003). Sport and tourism: A conceptual framework. Journal of Sport Tourism, 8, 21-26.

Gibson, H. (2002). Sport tourism at a crossroad? Considerations for the future. In S. Gammon \& J. Kurtzman (Eds.), Sport tourism: Principles and practice (pp. 123-140). Eastbourne, UK: LSA Publications No. 76

Gibson, H. I., Willming, C., \& Holdnak, A. (2003). Small-scale event sport tourism: Fans as tourists. Tourism Management, 
22(3), 181-190.

Goodrich, J. N. (2002). September 11, 2001 attack on America: A record of the immediate impacts and reactions in the USA travel and tourism industry. Tourism Management, 23, 573580.

Funk, D. C., \& James, J. D. (2001). The Psychological Continuum Model (PCM). A conceptual framework for understanding an individual's psychological connection to sport Sport Management Review, 4, 119-150.

Funk, D. C., Mahony, D. F., Nakazawa, M., \& Hirakawa, S., (2001). Development of the sport interest inventory (SII) Implications for measuring unique consumer motives at team sporting events. International Journal of Sports Marketing and Sponsorship, 3, 291-316.

Funk, D., Ridinger, L., \& Moorman, A. (2004). Exploring origins of involvement: Understanding the relationship between consumer motives and involvement with professional sport teams. Leisure Sciences, 26(1), 35-61.

Hall, C. M. (2002). Travel safety, terrorism and the media: The significance of the issue-attention cycle. Current Issues in Tourism, 5(5), 458-466.

Hall, C. M., \& O'Sullivan, V. (1996). Tourism, political instability and violence. In A. Pizam \& Y. Mansfeld (Eds.), Tourism, crime and international security issues (pp. 105-121). New York: John Wiley.

Hall, C. M., Timothy, D., \& David, D. (Eds.). (2003). Safery and security in tourism: Relationships, management, and marketing. Binghamton, NY: The Haworth Hospitality Press.

Johnson, L. (2001). The future of terrorism. American Behavioral Scientist, 44(6), 894-913.

Kennedy, P., Perrottet, C.. \& Thomas, C. (2003). Scenario planning after 9/11: Managing the impact of a catastrophic event. Strategy \& Leadership, 3l(1), 4-13.

Kennelly, M. (2005). 'Business as usual': Elite Australian athletes' viewpoints of terrorism post $9 / 11$. Unpublished bachelor honours' thesis, University of Technology, Sydney, Australia.

Kim, N., \& Chalip, L. (2004). Why travel to the FIFA World Cup? Effects of motives, background, interest, and constraints. Tourism Management, 25(6), 695-707.

Kurtzman, J., \& Zauhar, J. (2005). Sports tourism consumer motivation. Journal of Sport Tourism, 10(1), 21-31.

Kuto, B. K., \& Groves, J. L. (2004). The effect of terrorism: Evaluating Kenya's tourism crisis. e-Review of Tourism Research (eRTR), 2(4). http://ertr.tamu.edu/ appliedresearch.cfm?articleid $=68$

Lee, C., \& Taylor, T. (2005). The economic impact assessment of the FIFA World Cup. Tourism Management, 26(5), 595 . 603.

Lepp, A., \& Gibson, H. (2003). Tourist roles, perceived risk and international tourism. Annals of Tourism, 30(3), 606-624.

Litvin, S. W. (2004). A look back at SARS and SIP. e-Review of Tourism Research (eRTR), 2(1). http://ertr.tamu.edu/ appliedresearch.cfm

Liu, M., Vlahou, T., \& Roberts, M. (2004, March 8). Olympic insecurity. Newsweek. p. 22.

McIntosh, M. (1984). Security measures at the summer Olvmpics. Unpublished manuscript, University of Toronto Toronto, Canada.

Merari, A. (2002). Deterring fear: Government responses to terrorist attacks. Harvard International Review, Winter, 26-31.

Metcalfe, A. (2004, 23 March). Implementing a whole of government approach to national security and terrorism. $\mathrm{Na}$ tional Security Australia. Australian Government, Department of the Prime Minister and Cabinet Web site: http:// www.pm c.gov.au/s peeches/metcalfe/ whole govt_approach_2004-03-04.cfm (retrieved Feburary 17, 2005)

Moore, K. (1996, August 5). Munich's message. Sports Illustrated. p. 29.

Oriol, P. S. (2004). Fear and fantasy: The elsewheres of post-9/ 11 tourism. e-Review of Tourism Research (eRTR), 2(4). http:/ /ertr.tamu.edu/commentaries.cfm?articleid $=42$

Ritchie, B., Mosedale, L., \& King, J. (2002). Profiling sport tourists: The case of super 12 Rugby Union in the Australian Capital Territory, Australia. Current Issues in Tourism, 5(1), 33-44.

Sönmez, S., \& Graefe, A. (1998). Influence of terrorism risk on foreign tourism decisions. Annals of Tourism Research, 25 , 112-144.

Tarlow, P. (2002). Event risk management and safety. New York: John Wiley \& Sons.

Todd, N. (2004). Police review World Cup security. The Weekend Australian. http://www.theaustralian.news.com.au/ printpage $/ 0,5942,9641260,00 \mathrm{html}$ (retrieved May 24, 2004)

Toohey, K., \& Taylor, T. (2006). 'Here be dragons, here be savages, here be bad plumbing': Australian media representations of sport and terrorism. Sport in Society, 9, 71-93.

Toohey, K., Taylor, T., \& Lee, C. (2003). The FIFA World Cup 2002: The effects of terrorism on sport tourists. Journal of Sport Tourism, 8(3), 186-196.

Toohey, K., \& Veal, A. (2000). The Olympic games: A social science perspective. Oxon: $\mathrm{CABI}$.

Trail, G. T., Anderson, D. F., \& Fink, J. (2000). A theoretical model of sport spectator consumption behavior. International Journal of Sport Management, 3, 154-180.

Walsh, K. (2003, November 23). Tightest security ever guards World Cup final. The Sun-Herald, p. 7.

Wann, D. L., Melnick, M. J., Russell, G. W., \& Pease, D. G. (2001). Sport fans: The psychology and social impact of spectators. New York: Routledge.

Wicks, B. (2002). World Cup fans: Hooligans or tourists. In Proceedings of the Korean Academic Society of Tourism Management international Conference for the Success of the 2002 World Cup (pp. 22-35). Korea: Korean Academic Society of Tourism Management.

Zhang, J. J., Pease, D. C., Lam, E. T. C., Bellerive, L. M., Pham, U. L., Williamson, D. P., et al. (2001). Sociomotivational factors affecting spectator attendance at minor league hockey games. Sport Marketing Quarterly, I0(1), 43-56. 